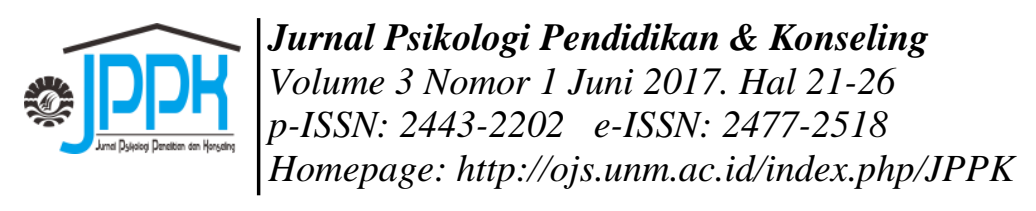

\title{
The relationship between family functioning and juvenile delinquency at SMKN 4 Pekanbaru
}

\author{
Trio Saputra \\ University of Lancang Kuning \\ Email: trio_saputra@unilak.ac.id
}

(Received: 02-Maret-2017; revised: 29-Maret-2017; published: 29-Juni-2017)

\begin{abstract}
Abstrct : This study aims to determine the relationship between family functioning juvenile delinquency. This study used 120 subjects students in SMK N 4 Pekanbaru, research data were collected using two scales, the scale of family function and delinquency with item number 53. Sampling in this study using non probabilitis sampling techniques, data analysis using product moment, with the help of SPSS 17.0 for Windows. Based on the analysis found that there is a negative relationship between family functioning juvenile delinquency, the correlation $\mathrm{p}=-0.5900 .000$. Then the hypothesis is accepted, meaning the lower the higher the family function of juvenile delinquency and conversely the higher the lower a family function of juvenile delinquency
\end{abstract}

Key word : family functioning; juvenile delinquency; student; pekanbaru

Copyright (C) 2017 Universitas Negeri Makassar.. This is an open access article under the CC BYNC-ND license (http://creativecommons.org/licenses/by-nc-nd/4.0/).

\section{INTRODUCTION}

Human life passes through several stages of development, including adolescence. Adolescence is a period of transition from childhood to adulthood with an age range between 12-22 years (Dahlan, 2010). Globally, adolescence takes place between the ages of 1222 years; $12-15$ years is the early adolescence, 15-18 years is the mid-adolescence, and 19-22 years is the final adolescence. Adolescents are very sensitive to outside influences. Adolescence is a period of transition from childhood to adulthood characterized by unstable emotions and attempts to show identity. In addition, adolescents are very much experiencing difficulty in their life as they are psychologically still unstable that it can disturb the order in the form of delinquency. Juvenile delinquency often creates anxiety and unpleasant feelings for the environment and the parents. Parental guidance and attention is needed so that adolescents do not fall for negativity (Sarwono, 2002).

Juvenile delinquency is an increasingly widespread phenomenon including student brawl, drunkenness, theft, drug abuse, and premarital sex. This is evidenced by the existing data, among others, based on a survey conducted by the National Commission for Child Protection (KPA) of 4500 adolescents in 12 major cities in Indonesia. The results of this survey showed that $62.7 \%$ of adolescents admitted to having had sex, $93 \%$ of adolescents had kissed, and $21 \%$ of adolescents had an abortion (Kompas, 2010). In relation to the internet, there are about four million pornographic websites. 90 thousand of them display child pornography. Meanwhile, the internet users according to research conducted by 
Yahoo Indonesia and Taylor Nelson Sofres in 2009 were mostly adolescents aged 15-19 years or $64 \%$. (Tempo, 2010).

According to Kartono (2006), "delinquency is a malicious behavior/misconduct or crime/mischief perpetrated by adolescents and is a symptom of social (pathological) disease in children and adolescents caused by a form of social neglect so that they develop deviant behavior". In observing the behavior of the students, the main focus here is on the behaviors classified as juvenile delinquency that the students do at the time when they are supposed to study. This does not only cover time to study at school, but also at home.

Juvenile delinquency includes all behaviors that deviate from the legal norms perpetrated by adolescents. Such behaviors will harm themselves and the people around them. Education experts agree that adolescents are those between the ages of 13-18. At these ages, a person has gone beyond childhood, but still not mature enough to be considered an adult. $\mathrm{He} / \mathrm{she}$ is in a transition period.

According to Kartono (2006), the high number of delinquency is the impact of the development of the modern era that makes everything faster. The rapid development of technology requires adolescents to immediately be able to master and follow the changes if they do not want to be left behind by other adolescents. This demand is a difficult task for today's adolescents. Skilled adolescents may avoid confusion, anxiety, and conflicts (internal conflicts and external conflicts), while unskilled adolescents are not competent and are excluded from association.

The problem of juvenile delinquency is considered very disturbing especially the society, either living in the city or in remote villages. The problem of juvenile delinquency has negative impacts on the surrounding environment, such as disturbing society, insecurity, and even as its members, their life is threatened. Lately, the problem of juvenile delinquency has become a national problem that is increasingly difficult to avoid, overcome, and fix (Darmawan, 2013). Based on the results of several studies, it is found that one of the factors causing the onset of juvenile delinquency is the non-functioning of the parents as a role model for their children (Hasan Al-Banna Mohamed, 2011).

According to Santrock (2006), the internal factors of juvenile delinquency include identity, self-control, age, gender, and expectations from education and values in schools. While the external factors consist of family, peer influence, socioeconomic class, and the environment quality. Family factor is very influential on the occurrence of juvenile delinquency. The lack of family support, such as the lack of parental attention to children's activities, the lack of effective discipline, and the lack of parental affection, can trigger the onset of juvenile delinquency. Research conducted by Petterson and Strouthamer-Loeber (Santrock, 1996) suggests that inadequate parental supervision of adolescents and ineffective and inappropriate application of discipline are very important in determining the emergence of juvenile delinquency. Family disputes or stress experienced by the family are also associated with delinquency.

The family has an important function in creating inner peace for adolescents. If they feel the warmth, affection and tranquility of their parents against them, then their souls will be at ease. Conversely, adolescents can also suffer and are encouraged to oppose and behave badly if the parents do not love them and do not understand what they are experiencing. In facing juvenile delinquency, wise parents can understand the circumstances of their children and help them overcome the problems they face. A family filled with warmth and affection and able to express attention and appreciation openly will enable adolescents to develop basic trust in their environment and give them widespread opportunities for growth.

Maslihah (2011) states that the family environment is a land to develop various abilities through daily experiences in the family. The encouragement given and the competitive climate between family members performed in a healthy way have an important influence in the development of an adolescent's psychology, especially to spur them to continue to excel and develop themselves. In addition, family environment in which there is a high level of respect and tolerance will allow conflicts to be prevented and minimize family pressure and tension. Adolescents in this family environment also learn not to be selfish, to share with other family members, to respect the rights of others, to be self-reliant and to take full responsibility for all they have done.

Emphasizing the importance of the family environment as an educational environment for the individual will certainly relate to the extent of the family functioning in 
the creation of and the availability of opportunities for children to actualize the potential they have to grow and develop optimally. Family harmony can be seen and reflected in the attitude and outlook on life, the passion, and personality patterns of its members (Yulia Herawaty and Ratna Wulan, 2013).

The expression of family functioning can be conveyed through genuine affection and attention, respect among family members, care, healthy communication patterns, and emotional support with proportional levels. All of these things create a harmonious climate and intimate relationships within the family. These values are accepted, absorbed and then deeply experienced by adolescents so as to make them realize that there is meaning in their life, a family that sincerely loves and accepts them unconditionally.

Family functioning also shows that there is an opportunity for every individual in the family to grow, to be actively involved in helping to make decisions and solve family problems, and that there are tasks and responsibilities to be done by them. This makes adolescents feel that they are special, meaningful, valuable, reliable, and needed by the family. In other words, the involvement of adolescents in family activities makes them feel valuable and meaningful that leads them to the meaningfulness of life.

Yuanita (2011) explains that the family that could be the cause of delinquency is a family whose supervision of its adolescent members is somewhat difficult to implement properly, applying less effective discipline, having inadequate economic condition, and that is not harmonious. According Sudarsono, (2004), the family that becomes the cause of the emergence of delinquency can be an abnormal family (broken home) and family with an unfavorable number of members.

There are some views or assumptions about family. According to Durkheim (Azwar, 2000), families are social institutions as a result of political, economic and environmental factors. Yulia Herawaty and Ratna Wulan (2013) states that in general family functions include: sexual arrangement, reproduction, socialization, maintenance, placement of children in society, individual needs satisfaction and social control. Hurlock (2000) states that family functioning is when all family members are happy that is characterized by a reduction in tension, disappointment and satisfaction of all the circumstances and existence of themselves
(Existence and Self-actualization) which includes physical, mental, emotional, and social aspects. Safe and protected conditions perceived by family members may allow for a reasonable development for the family members.

Kartono (2006) argues that family is the first institution in children's life where they study and declare themself as a social creature. In most families, a child experiences an intimate interaction. Everything a child does affects the family, and vice versa. The family provides the basis for the formation of behavior, personality, morals and education for the child. The experience of interaction within the family will also determine the behavior patterns of the child against others in the community. The success or failure of a family in carrying out the functions that exist within the family gives a relatively large influence on the child's behavior.

Based on the above description, it can be concluded that family is one important factor affecting juvenile delinquency. The way a family provides direction and upbringing in adolescents will determine the behaviors of adolescents in community life. This is because in adolescence, adolescents will face a wider social environment that needs the serious attention of the family in order to fit well in the social environment. Family as the closest environment of adolescents has a primary function as a means of forming family members which includes the prevention of juvenile delinquency.

\section{METHOD}

In collecting data, this research used two scales, family functioning scale and juvenile delinquency scale. Samples taken were 100 adolescents at SMKN 4 Pekanbaru. This research is a quantitative research with summated ratings method which contains favorable and unfavorable statements (Azwar, 2000). Data analysis used in this research was statistical analysis. The statistical data analysis model used to test the hypothesis of this research is Pearson's product-moment correlation.

\section{FINDINGS AND DISCUSSION}


Based on the data obtained from the instrument, the researcher then conducted a quantitative analysis using SPSS 17.0 for windows to know the value of validity and reliability of each instrument scale. From these tests, the following results were obtained:

1) Juvenile Delinquency Scale

The scale validity test was based on the criteria that the item is valid if it has a total correlation of (rxy) $\geq 0.3$ and above. The results of analysis performed on the juvenile delinquency scale showed that 53 of 72 items tested were valid and had a validity coefficient value between 0.316 0.739 . The rest of 19 items were not valid, namely: 3. 9, 11, 16, 20, 22, 29, 31, 34, 38, 44, $46,47,51,52,54,56,62,71$. The value of alpha reliability coefficient $(\alpha)$ on the juvenile delinquency scale was 0.922 .

2) Family Functioning Scale

The scale validity test was based on the criteria that the item is valid if it has a total correlation of (rxy) $\geq 0.3$ and above. The results of analysis performed on the family functioning scale showed that 50 items tested were valid and had a validity coefficient value between 0.304-0.778. There were 2 items not valid, namely 1,47 . The value of alpha reliability coefficient $(\alpha)$ on the family functioning scale was 0.945 .

Before analyzing research data, requirements analysis was performed in the form of normality test as a requirement for testing the correlation value so that the conclusions drawn do not deviate from the truth. This assumption test was done with the help of SPSS 17.0 for windows computer program.

\section{a) Normality Test}

Normality test aimed to find out whether the variables in this research were normally or not. Normality test was performed on the score distribution of family functioning and juvenile delinquency, using the one-sample kolmogorovsmirnov technique through SPSS 17.0 for windows program. The assumption used to know whether or not the data was normally distribution is if $p>0.05$ then the distribution is normal, but if $\mathrm{p}<0.05$ then the distribution is not normal.

Normality test results showed that the family functioning score was in the normal category (K-SZ $=0.931, \mathrm{p}>0.05)$. Juvenile delinquency was also in the normal category (K$\mathrm{SZ}=0.351, \mathrm{p}>0.05)$.

1. Hypothesis Testing

After performing assumption test that is normality test, researcher did hypothesis testing.
Hypothesis testing was intended to determine whether there was a relationship between family functioning variable and juvenile delinquency variable. Hypothesis testing was done by using statistical technique of Pearson's product moment correlation.

The hypothesis testing result revealed that correlation value between family functioning variable and juvenile delinquency variable was $r$ $=-0.590, \mathrm{p}=0.000, \mathrm{p}<0,05$. This indicates a significant negative relationship between family functioning and juvenile delinquency. Based on data analysis above, it can be concluded that the hypothesis in this research is tenable.

This research shows a significant negative relationship between family functioning and juvenile delinquency. This means that the higher the functioning of family is, the lower the possibility of an adolescent to get involved in juvenile delinquency will be. Conversely, the lower the family functioning is, the higher the juvenile delinquency will be. In general, students of SMK N 4 Pekanbaru have family functioning that is categorized as high.

Furthermore, Hasan Al-Banna Mohamed (2011) said that the background of family functioning can affect the likelihood of adolescents becoming delinquent. A family with insufficient cohesiveness (a lack of close relationship between family members), and an unharmonious relationship within the family is a predictor of the possibility of delinquency.

Family also has a role in shaping the personality of a teenager. In a healthy and functioning family, adolescents will receive basic exercises in developing good social attitudes, and controlled behaviors. In addition, they also gain understanding about rights, obligations, responsibilities and learn to work together and share with others. In other words, a child in a family colored with warmth and intimacy will form the principle of a good group life as the foundation of life in the community later. A less family functioning environment is often thought to contribute to the emergence of juvenile delinquency, as adolescents raised by nonfunctioning family will perceive their homes as unpleasant places and do things that violate norms in society as a way of expressing protest at parents.

Furthermore, (Hurlock, 2000) adds that adolescents with poor family relationships can also develop a poor relationship with people outside the home. These conditions if supported by a less conducive environment and poor 
personality traits will trigger the emergence of various deviations of behavior and negative actions that violate the rules and norms that exist in the community.

Elliott, Lach, and Smith (2005) also said that parenting styles are highly correlated and have a major influence on the emergence of criminal and anti-social behavior in adolescents. However, the style of parenting can not be separated from the influence of the environment and factors from outside themself. For example, parents who have limited income and parents who have poor relationship with neighbors will find it much more difficult to apply an effective parenting style to their children. Adolescents who have a combination of parents who are able to control and use an effective parenting style will avoid delinquent deeds because they have enough stock in knowing which things are good and are not good to do. Hasbahuddin (2015) said that efforts to prevent juvenile delinquency is to develop character education from the family and instill the value needed to develop children's self to prevent misbehavior.

Kartono (2006) argues that family is the first institution in children's life where they study and declare themself as a social creature. In most families, a child experiences an intimate interaction. Everything a child does affects the family, and vice versa. The family provides the basis for the formation of behavior, personality, morals and education for the child. The experience of interaction within the family will also determine the behavior patterns of the child against others in the community. The success or failure of a family in carrying out the functions that exist within the family gives a relatively large influence on the child's behavior. Referring to what Petzold says, the concept of family functioning is crucial in studying children's behavioral problems, as families are responsible for supporting, maintaining, guiding and monitoring children.

Based on the description above, it can be concluded that the family is one important factor that affects juvenile delinquency. The functioning of the family is the condition in which a family is able to perform well the basic functions of daily life in the family, which include the provision of a sense of security to the children because they become stable group members, the fulfillment of the physical and psychological needs of the children, and the family can be expected in solving the problems faced by each child in life. If a family can not run one function of the family functioning, then it will affect the behavior of adolescents in community life. Thus, it can be concluded that the family functioning of the students at SMKN 4 Pekanbaru is categorized high with low level of delinquency.

In the end, nothing is perfect. Similarly, there are still many weaknesses found in this research during its process. The weaknesses of this research came from several things, among others, the process of preparation and characteristics of the scale used. Items on the scales adapted and modified by the researcher are deemed less able to explore the actual state of the subjects. In addition to the characteristics of instruments, the weakness of this research can be seen from the composition of research subjects that consisted only of students of class X and IX considered by the researcher not able to actually describe the true state of the existing population.

\section{CONCLUSION AND SUGGESTION}

The conclusions of this research on the relationship between family functioning and juvenile delinquency at SMK N 4 is: there is a significant negative relationship between the family functioning and juvenile delinquency, where the higher the functioning of the family is, the lower the juvenile delinquency will be, and, on the other hand, the lower the family functioning is, the higher the juvenile delinquency will be.

Suggestion

Based on the results that have been achieved, then the researcher puts forward some suggestions as follows:

The results of this research are expected to be a knowledge material for parents to pay attention to children's development and educate them in the family environment. The family is expected to be a family capable of functioning or performing duties and responsibilities. Parents should give good examples to their children and help solve problems that arise in adolescence so that adolescents can know a good solution so as not to cause misbehaviour and mischief. Furthermore, the school should be able to facilitate the needs of adolescents so as not to engage in juvenile delinquency and should require students to follow positive activities undertaken in school such as extra-curricular activities that include basketball, soccer, PMR (youth red cross), etc. The next researchers who are interested in researching the problem of 
juvenile delinquency and family functioning are expected to find other aspects that can better represent the research done so that its contribution is more visible. They need to pay attention to the items of the scales of research and the procedure of collecting research data so as to obtain data that is honest and appropriate with the subject circumstances. Sampling techniques should be more varied, for example by involving other school students so that comparative test can be done.

\section{REFERENCES}

Azwar, S. (2008). Sikap Manusia: Teori dan Pengukurannya. Sikap Manusia: Teori Dan Pengukurannya, 1988. https://doi.org/10.1038/cddis.2011.1

Dahlan, D. (2010). Psikologi Perkembangan Anak dan Remaja. Jakarta: PT.BPK Gunung Mulia.

Darmawan, H. (2013). Kenakalan remaja. Jakarta: PT Raja Grafindo Persada, 3.

Elliott, I. M., Lach, L., \& Smith, M. Lou. (2005). I just want to be normal: A qualitative study exploring how children and adolescents view the impact of intractable epilepsy on their quality of life. Epilepsy and Behavior, 7(4), 664-678. https://doi.org/10.1016/j.yebeh.2005.07.004

Hasan Al-Banna Mohamed, M. A. G. S. A. B. (2011). Panduan Al-Quran dan Integrasi Ilmu Saintifik Ke Arah Pemantapan Sistem Pengurusan Berkualiti. In International Seminar on Wahyu Asas Tamadun 2 SWAT 2011.
Hasbahuddin. (2015). Jurnal Psikologi Pendidikan \& Konseling kecenderungan penyalahgunaan pendahuluan, 1, 93-104.

Hurlock, E. B. (2000). Psikologi Perkembangan: Suatu Pendekatan Sepanjang Rentang Kehidupan. Erlangga.

Kartono, K. (2006). Phatologi Sosial 2. Kenakalan Remaja. Jakarta: PT. Raja Grafindo Persada.

Maslihah, S. (2011). Studi Tentang Hubungan Dukungan Sosial, Penyesuaian Sosial Di Lingkungan Sekolah Dan Prestasi Akademik Siswa Smpit Assyfa Boarding School Subang Jawa Barat. Jurnal Psikologi Undip. https://doi.org/10.14710/jpu.10.2.103-114

Santrock, J. W. (2000). Adolescence: An introduction (6th ed.). Adolescence: An introduction (6th ed.).

Santrock, J. W. (2006). Life-span development (10th ed.). Life-Span Development (10th $E d$.).

Sarwono, W. (2002). Psikologi Remaja. Jakarta: PT. Raja Grafindo Persada.

Sudarsono. (2004). Kenakalan Remaja. Jakarta: PT. Rineka Cipta.

Yuanita, S. (2011). Fenomena Dan Tantangan Remaja Menjelang Dewasa. Yogyakarta: Brilliant Book.

Yulia Herawaty, \& Ratna Wulan. (2013). Hubungan Antara Keberfungsian Keluarga dan Daya Juang Dengan Belajar Berdasar Regulasi Diri Pada Remaja. Jurnal Psikologi UIN Sultan Syarif Kasim Riau, 9(Desember), $138=147$. 